ДОСЛІДЖЕННЯ НОВОГО КОЖУХОТРУБНОГО

ТЕПЛООБМІННИКА ДЛЯ ВИКОРИСТАННЯ В СИСТЕМАХ

ГЕОТЕРМАЛЬНОГО ТЕПЛОПОСТАЧАННЯ

Н. Б. Сильнягіна, стариий науковий співробітник

E-mail: nbs77@rambler.ru

O. С. Степанова, стариий науковий співробітник

E-mail: htplab@ukr.net

Д. М. Чалаєв, кандидат технічних наук, провідний науковий співробітник

E-mail:htplab@ukr.net

О. О. Переяславцева, кандидат технічних наук, провідний науковий співробітник

E-mail: alena_p11@ukr.net

Р. С. Базєєв, проідний. інженер-технолог

E-mail: htplab@ukr.net

Інститут технічної теплофізики НАН Украӥни, м. Киӥв

Анотація. Геотермальні ресурси $є$ практично невичерпним екологічно чистим джерелом відновлюваної енергії. В Україні $\epsilon$ великі запаси гарячих термальних вод, які практично не використовуються для потреб теплоенергетики. В Україні переважна більшість родовищ геотермальних ресурсів відносяться до високомінералізованих, де вміст мінеральних сполучень в підземних водах перевищує 40 г/л, а на деяких родовищах досягає 150 - 300 г/л. Враховуючи екологічний аспект, єдино прийнятним варіантом використання таких вод є створення геотермальних циркулячійних систем зі зворотнім закачуванням відпраџьованого геотермального флюїду у водоносний пласт. Однією з технічних проблем, що перешкоджають широкому застосуванню технології вилучення теплової енергії з нагрітих високомінералізованих розсолів, $\epsilon$ інтенсивне солевідкладення в теплообмінному обладнанні. Негативний вилив прочесу відкладення солей на теплообмінній поверхні полягає в збільшенні термічного опору, що призводить до погіршення теплових характеристик теплообмінника. Ефективним шляхом вирімення проблеми солевідкладення в теплообмінних апаратах, призначених для експлуатації в системах геотермального теплопостачання, є застосування трубчастих теплообмінників з профільованими трубами, які можуть істотно знизити темп відкладення солей на теплообмінних поверхнях і одночасно інтенсифікувати теплообмін за рахунок штучної турбулізації пристінного шару потоку теплоносія. В ІТТФ НАН України проведені дослідження $i$ пропонується перспективна конструкиія 
теплообмінника для геотермальних теплових пунктів, в якому в якості теплообмінних елементів використовуються тонкостінні гнучкі нержавіючі профільовані труби з можливістю працювати з високомінералізованими розчинами (298 г/л). Проведені експериментальні дослідження показали, що використання теплообмінних апаратів на основі профільованих труб у системах геотермального теплопостачання дозволить забезпечити довготривалу роботу теплообмінних апаратів без проведення додаткових заходів з очищення поверхонь.

Ключові слова: трубчастий теплообмінник, гофровані труби, коефіцієнт теплопередачі, геотермальний флюйд, солевідкладення

Актуальність. Геотермальні ресурси є практично невичерпним екологічно чистим джерелом відновлюваної енергії. В Україні $є$ великі запаси гарячих термальних вод, які практично не використовуються для потреб теплоенергетики. За даними останнього Всесвітнього геотермального конгресу, який проходив у 2015 році в м. Мельбурні (Австралія) [1], обсяги використання геотермальної енергії в Україні становлять 118,8 ТДж за рік, що в кілька разів менше, ніж в сусідніх Польщі, Словаччині, Румунії.

В Україні переважна більшість родовищ геотермальних ресурсів відносяться до високомінералізованих, де вміст мінеральних сполучень в підземних водах перевищує 40 г/л, а на родовищах Дніпровсько-Донецької западини досягає 150 300 г/л [2]. Враховуючи екологічний аспект, єдиним прийнятним варіантом використання таких вод $є$ створення геотермальних циркуляційних систем зі зворотнім закачуванням відпрацьованого (охолодженого) геотермального флюїду у водоносний пласт.

Аналіз останніх досліджень та публікацій. Найпростіша схема геотермальної циркуляційної системи (ГЦС) представлена на рис. 1. Геотермальні циркуляційні системи призначені для доставки геотермального флюїду 3 водоносного пласту на поверхню землі, відбору теплоти та примусового повернення його в пласт, тобто створення замкненого циркуляційного контуру: водоносний пласт - видобувна свердловина - теплообмінник - насос нагнітальна свердловина - пласт. Завдяки організації таких контурів з родовища вилучається практично вся теплота геотермального флюїду, а також частина тепла 
земних порід, яке відноситься до так званих петротермальних енергетичних запасів.

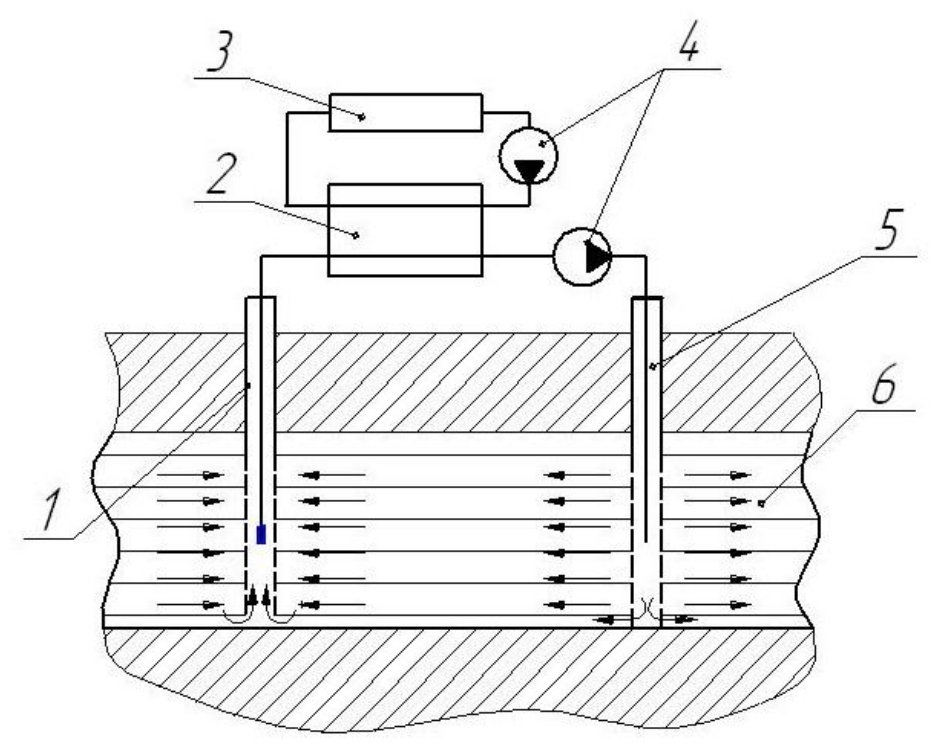

\section{Рис. 1. Технологічна схема геотермальної циркуляційної системи (ГЦС):}

1 - видобувна свердловина; 2 - теплообмінник-утилізатор геотермальної енергії; 3 - споживач теплової енергії; 4 - циркуляційні насоси; 5 - нагнітальна свердловина; 6 - водоносний пласт

Крім того, в результаті циркуляції геотермального флюїду в водоносному пласті підтримується сталий пластовий тиск, що дозволяє суттєво (в 2 - 2,5 рази) підвищити дебет свердловини i, відповідно, кількість утилізованої теплової енергії, а також значно скоротити витрати електричної енергії на живлення видобувного насоса.

Однією 3 технічних проблем, що перешкоджають широкому застосуванню технології вилучення теплової енергії з нагрітих високомінералізованих розсолів, $€$ інтенсивне солевідкладення в теплообмінному обладнанні. Негативний вплив процесу відкладення солей на теплообмінній поверхні полягає в збільшенні термічного опору, що призводить до погіршення теплових характеристик теплообмінника. Відкладення солей викликає також зменшення прохідного перетину каналів і збільшення опору руху теплоносія.

Основна причина солевідкладення при прокачуванні термальних вод - це зміна термобаричних умов (зниження температури і тиску), що призводить до утворення нестабільних перенасичених розчинів і відкладенню осаду. Швидкість 
утворення твердих відкладень на теплообмінній поверхні залежить від фізикохімічних властивостей і режиму руху геотермального флюїду. В залежності від мінерального складу підземні води розділені на три основні класи: гідрокарбонатні, сульфатні і хлоридні [3]. Всередині класів виділені підкласи: катіоно-кальцієвий, магнієвий і натрієвий. Відповідно, за переважним вмістом неорганічних сполук у відкладеннях виділяється три групи солей: карбонати, сульфати і хлориди.

Експериментальні дослідження кінетики кристалізації солей 3 розчинів геотермальних вод показали, що швидкість утворення відкладень карбонату кальцію на поверхні нагрівання теплообмінника залежить від числа Re: за Re = 1500 швидкість утворення відкладень становить 0,18 кг/(м².год.) і зі збільшенням числа $\operatorname{Re}\left(>10^{5}\right)$ знижується до 0,05-0,06 кг/(м²·год.). При цьому в області малих значень $\operatorname{Re}(<2000)$ відкладення мають рихлу структуру з густиною 1,6-1,8 кг/ $\mathrm{cm}^{3}$ i легко видаляються з теплообмінної поверхні. Зі збільшенням числа Re густина відкладень зростає і при високих числах $\operatorname{Re}\left(>10^{5}\right)$ досягає 2,5-2,7 кг/см ${ }^{3}[4,5]$.

Ефективним шляхом вирішення проблеми солевідкладення в теплообмінних апаратах, призначених для експлуатації в системах геотермального теплопостачання, є застосування трубчастих теплообмінників 3 профільованими трубами, які можуть істотно знизити темпи відкладення солей на теплообмінних поверхнях i одночасно інтенсифікувати теплообмін за рахунок штучної турбулізації пристінного шару потоку теплоносія [6]. Інтенсифікація тепловіддачі із застосуванням профільованої поверхні в загальному випадку відбувається за рахунок більш раннього переходу від ламінарного до турбулентного режимів у порівнянні з гладкою поверхнею. Так, якщо при швидкості рідини в круглій гладкій трубі в умовах стабілізованого потоку область перехідного режиму лежить в межах $2300<\operatorname{Re}<10000$, то в каналах складної форми ця область, як показує досвід, знаходиться значно нижче, в межах $50<\operatorname{Re}<2000$ [7].

Вітчизняною промисловістю освоєне виробництво гнучких нержавіючих профільованих труб невеликого діаметра. Раніше нами було показано перспективність використання цих труб для створення теплообмінних апаратів [8]. Така теплообмінна поверхня характеризується компактністю, невисокою 
питомою вартістю, можливістю створення складних теплообмінних поверхонь за рахунок “згину” теплообмінної поверхні і закрутки пучка профільованих труб. Профільовані труби забезпечують турбулентність поблизу поверхні стінки труби, тим самим зменшуючи товщину теплового пограничного шару. У результаті покращується перемішування рідини поблизу стінки труби, завдяки відривним збуренням від стінки до основного потоку, тим самим досягається збільшення загального коефіцієнта теплопередачі в теплообмінних системах.

Мета дослідження - особливості теплообміну для профільованих труб при роботі на теплоносіях, що мають підвищений вміст солей і підвищену густину. Відсутність цих даних ускладнює проектування теплообмінних апаратів i оптимізацію їх параметрів.

Матеріали і методи дослідження. Для вирішення цього завдання в ІТТФ НАН України створено експериментальний стенд [7-8] і проведені дослідження інтенсивності теплопередачі при використанні тонкостінних гофрованих труб різних модифікацій для роботи на модельних теплоносіях. Як модельне середовище був взятий природний геомінеральний розчин, який $\epsilon$ високомінералізованим розчином зі складним мінеральним і елементним складом (табл. 1). Мінералізація розчину складає 298 г/л, густина - 1192 кг $/ \mathrm{M}^{3}$ при $20{ }^{\circ} \mathrm{C}$.

\section{1. Основний композиційний склад модельного розчину}

\begin{tabular}{|c|c|}
\hline Склад & Кількість, г/л \\
\hline Хлориди & 167,15 \\
\hline Сульфати & 1,75 \\
\hline Кальцій & 6,03 \\
\hline Магній & 0,57 \\
\hline Калій & 0,43 \\
\hline Натрій & 122,00 \\
\hline
\end{tabular}

Дослідження проводилися при швидкостях теплоносія в трубах $0,5 \ldots 1,1 \mathrm{~m} / \mathrm{c}$, що відповідає числам Рейнольдса $\mathrm{Re}=4500-9500$. Результати порівняльних випробувань трубчатого теплообмінника з профільованою внутрішньою трубою 
при роботі на системах “вода - вода" і “високомінералізоване середовище - вода" показали, що лімітуючим фактором теплопередачі є внутрішня поверхня труби, в якій циркулює високомінералізований розчин [8].

Результати досліджень та їх обговорення. Дослідження показали, що незважаючи на підвищену густину високомінералізованого розчину порівняно 3 водою, профільовані труби утворюють ефективну турбулізацію пристінного шару і забезпечують високі коефіцієнти тепловіддачі. Характер впливу режиму руху теплоносія на інтенсивність тепловіддачі показаний на рис. 2 у вигляді залежності $\mathrm{Nu}=\mathrm{f}(\mathrm{Re})$. Отримані дані дозволяють оптимізувати швидкість руху теплоносія $\mathrm{i}$ співвідношення перерізу внутрішнього і кільцевого каналів при проектуванні трубчатих теплообмінників, призначених для експлуатації в системах геотермального теплопостачання.

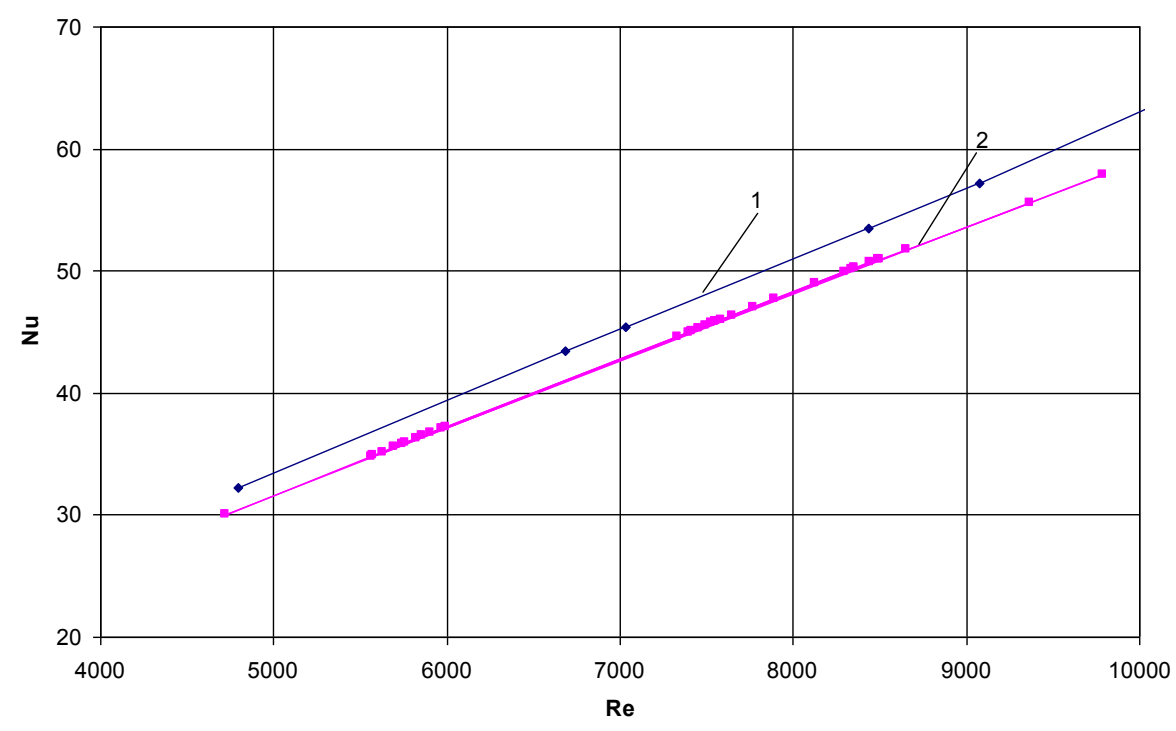

Рис. 2. Залежність числа Нусельта (Nu) від числа Рейнольдса (Re) в теплообмінниках на основі профільованої поверхні для систем “вода - вода" та "вода - високомінералізоване середовище":

1 - система “вода - вода"; 2 - система “високомінералізоване середовище вода"

Висновки i перспективи. Проведені експериментальні дослідження показали, що застосування гнучких нержавіючих профільованих труб в теплообмінних апаратах для систем геотермального теплопостачання дозволяє 
створити високу турбулентність потоку при відносно низьких швидкостях теплоносія, що забезпечує великі коефіцієнти тепловіддачі в апараті навіть при використанні високомінералізованих середовищ.

Ефективна турбулізація потоку теплоносія і створення режиму автоколивань теплообмінних трубок при русі теплоносія сприяють попередженню утворення відкладень на стінках трубок, завдяки чому вирішується актуальна проблема забруднення i чищення теплообмінного обладнання. Можлива експлуатація теплообмінників такого типу без операцій очищення протягом всього періоду роботи, оскільки товщина забруднень у профільованих трубках після певного проміжку часу роботи практично стабілізується на допустимому рівні.

Дослідження проводяться за підтримки програми наукових досліджень НАН України "Ресурс-2" (проект Р 5.10.1)

\section{Список літератури}

1. Оцінка перспективного використання геотермальних вод України для централізованого енергопостачання: звіт по НДР / Інститут технічної теплофізики НАН України. К., 2009. № Держреєстрації 0101U002849.

2. Lund S.W., Boyd T.L. Direct utilization of geothermal energy 2015 word wade review. Geothermic. 2016. 60. P. 66-93.

3. Алхасов А.Б. Возобновляемые источники энергии. М.: Издательский дом МЭИ, 2016. 270 с.

4. Ахмедов Г.Я. Кинетика роста отложений карбоната кальция в геотермальных системах. Теплоэнергетика. 2009. № 11. С. 13-17.

5. Редько А.Ф., Онищенко А.А. Методики исследований солеотложений в геотермальніх системах теплоснабжения. Энергосбережение. Энергетика. Энергоаудит. 2013. № 2 (108). С. 40-44.

6. Лобанов И.Е. Теоретические аспекты исследования интенсификации теплообмена с использованием локальных турбулизаторов потока в перспективных компактных применяемых в сельском хозяйстве трубчатых теплообменных аппаратов. Экономика: экономика и сельское хазяйство. 2017. № 1 (13).

7. Грабов Л.Н., Чалаев Д.М., Переяславцева Е.А., Сильнягина Н.Б. Разработка конкурентноспособных трубчатых теплообменных аппаратов. Наукові праці ОНАХТ. 2014. Вип. 45, т. 2. С. 93-97.

8. Чалаєв Д.М., Шматок О.I., Грабова Т.Л., Сильнягіна Н.Б. Розробка та дослідження енергоефективних кожухотрубних теплообмінників для високомінералізованих середовищ. Збірник праць VI Міжнародної науковопрактичної конференції “Інноваційні енерготехнології”. Одеса, 2017. С. 121-125. 


\section{References}

1. Otsinka perspektyvnoho vykorystannia heotermalnykh vod Ukrainy dlia tsentralizovanoho enerhopostachannia: zvit po NDR (2009). [Estimation of the prospective use of geothermal waters of Ukraine for centralized energy supply: research and development report]/ Instytut tekhnichnoi teplofizyky NAN Ukrainy. $\mathrm{Nu}$ Derzhreiestratsii 0101U002849.

2. Lund, S.W., Boyd, T.L. (2016)/ Direct utilization of geothermal energy 2015 word wade review. Geothermic, 60, 66-93.

3. Alhasov, A.B. (2016). Vozobnovlyaemyie istochniki energii [Renewable energy sources]. Izdatelskiy dom MEI, 270.

4. Ahmedov, G. Ya. (2009). Kinetika rosta otlozheniy karbonata kaltsiya v geotermalnyih sistemah [Growth kinetics of calcium carbonate deposits in geothermal systems]. Teploenergetika, 11, 13-17.

5. Redko, A. F., Onischenko, A. A. (2013). Metodiki issledovaniy soleotlozheniy v geotermalnIh sistemah teplosnabzheniya [Research methods of salt deposits in geothermal heating systems]. Energosberezhenie. Energetika. Energoaudit., 2 (108), 4044.

6. Lobanov, I. E. (2017). Teoreticheskie aspektyi issledovaniya intensifikatsii teploobmena $\mathrm{s}$ ispolzovaniem lokalnyih turbulizatorov potoka $\mathrm{v}$ perspektivnyih kompaktnyih primenyaemyih $\mathrm{v}$ selskom hozyaystve trubchatyih teploobmennyih apparatov [Research theoretical aspects of heat transfer intensification using local flow turbulators in promising compact agriculture tubular heat exchangers]. Ekonomika: ekonomika i selskoe hazyaystvo, 1(13).

7. Grabov, L. N., Chalaev, D. M., Pereyaslavtseva, E. A., Silnyagina, N. B. (2014). Razrabotka konkurentnosposobnyih trubchatyih teploobmennyih apparatov [Development of competitive tubular heat exchangers ]. NaukovI pratsI ONAHT, 45 (2), 93-97.

8. Chalaiev, D. M., Shmatok, O. I., Hrabova, T .L., Sylniahina, N. B. (2017). Rozrobka ta doslidzhennia enerhoefektyvnykh kozhukhotrubnykh teploobminnykiv dlia vysokomineralizovanykh seredovyshch [Development and research of energy-efficient shell-and-tube heat exchangers for high-mineralized environments]. Zbirnyk prats VI Mizhnarodnoi naukovo-praktychnoi konferentsii "Innovatsiini enerhotekhnolohii", Odesa, 121-125.

\section{ИССЛЕДОВАНИЕ НОВОГО КОЖУХОТРУБНОГО ТЕПЛООБМЕННИКА ДЛЯ ИСПОЛЬЗОВАНИЯ В СИСТЕМАХ ГЕОТЕРМАЛЬНОГО ТЕПЛОСНАБЖЕНИЯ Н. Б. Сильнягина, О. Е. Степанова, Д. М. Чалаев, Е. А. Переяславцева, Р. Е. Базеев}

Аннотация. Геотермальные ресурсы представляют собой практически неисчерпаемый экологически чистый источник возобновляемой энергии. В Украине существуют большие запасы горячих термальных вод, которые практически не используются для потребностей теплоэнергетики. В Украине подавляющее большинство месторождений геотермальных ресурсов относятся $\kappa$ высокоминерализированным, где содержание минеральных соединений в подземных водах превышает 40 г/л, а на некоторых месторождениях достигает 
150 - 300 г/л. Учитывая экологический аспект, единственно приемлемым вариантом использования таких вод является создание геотермальных цчиркуляциионных систем с обратным закачиванием отработанного геотермального флюида в водоносный пласт. Одной из технических проблем, которые препятствуют широкому применению технологии извлечения тепловой энергии из нагретых высокоминерализированных рассолов, является интенсивное солеотложение в теплообменном оборудовании. Негативное влияние проиесса отложения солей на теплообменной поверхности заключается в увеличении термического сопротивления, которое приводит к ухудшению тепловых характеристик теплообменника. Эффективным путем решения проблемы солеотложения в теплообменных аппаратах, предназначенных для эксплуатации в системах геотермального теплоснабжения, является применение трубчатых теплообменников с профилируемыми трубами, которые могут существенно снизить темп отложения солей на теплообменных поверхностях и одновременно интенсифицировать теплообмен за счет искусственной турбулизации пограничного слоя потока теплоносителя. В ИТТФ НАН Украинь проведень исследования и предлагается перспективная конструкиия теплообменника для геотермальных тепловых пунктов, в котором в качестве теплообменных элементов используются тонкостенные гибкие нержавеющие профилированные трубы с возможностью работать с высокоминерализированными растворами (298 2/л). Проведенные экспериментальные исследования показали, что использование теплообменных аппаратов на основе профилированных труб в системах геотермального теплоснабжения позволит обеспечить длительную работу теплообменных аппаратов без проведения дополнительных мероприятий по очистке поверхностей.

Ключевые слова: трубчатый теплообменник, гофрированные трубы, коэффициент теплопередачи, геотермальный флюид, солеотложсение

\title{
RESEARCH OF A NEW SHELL AND TUBE HEAT EXCHANGER FOR USE IN GEOTHERMAL HEATING SYSTEMS
}

\author{
N. Silnyagina, O. Stepanova, D. Chalaev, E. Pereyaslavtseva, R. Bazeev
}

Abstract. Geothermal resources are virtually inexhaustible, environmentally friendly source of renewable energy. There are large reserves of hot thermal waters, which are practically not used for the needs of thermal power in Ukraine. The vast majority of geothermal deposits are highly mineralized in Ukraine, where the content of mineral compounds in groundwater exceeds $40 \mathrm{~g} / \mathrm{l}$, and in some deposits reaches 150 $300 \mathrm{~g} /$. Considering the environmental aspect, the only acceptable use of such waters is the creation of geothermal circulation systems with re-injection of the spent geothermal fluid into the aquifer. One of the technical problems that prevent the widespread use of technology for extracting thermal energy from heated highly mineralized brines is the intensive deposition of salts in heat exchange equipment. The negative effect of the salt deposition process on the heat exchange surface is an increase of thermal resistance, which leads to a deterioration in the thermal characteristics of the heat exchanger. An effective way to solve the problem of scaling in heat exchangers designed for operation in geothermal heat supply systems is the use of tubular heat exchangers with corrugated tubes that can significantly reduce the salt deposition rate on the heat exchange 
surfaces and simultaneously intensify heat transfer due to simulated turbulization of the near-wall heat carrier flow. The research was carried out and the promising design of a downhole heat exchanger in which thin-walled flexible stainless corrugated tubes used with the ability to work with highly mineralized solutions $(298 \mathrm{~g} / \mathrm{l})$ as heat exchange elements was proposed by the IET of the National Academy of Sciences of Ukraine. As experiments show, the use of heat exchangers based on corrugated tubes in geothermal heat supply systems will ensure the long-term operation of heat exchangers without additional measures to clean the surfaces.

Key words: shell and tube heat exchanger, corrugated tubes, heat transfer coefficient, geothermal fluid, salt deposition 